\title{
ENTERTAINING ANGELS: THEIR PLACE IN CONTEMPORARY THEOLOGY ${ }^{1}$
}

Lawrence Osborn

\section{Summary}

Taking as its starting point a survey of Karl Barth's angelology, this essay explores the potential role of angelology in contemporary orthodox theology. It outlines a possible structure for angelology by presenting angels in terms of both their function (as ministering spirits) and being (as inhabitants of heaven understood as a dimension of creation). The essay indicates various roles for angelology: as a defence of the mystery of creation and its openness to God; as a possible element in dialogue with post-materialism (particularly in its New Age manifestations); and as an aspect of contemporary Christian spirituality.

\section{Introduction: Why Angels?}

Angels have never been a major element in evangelical theology. On the contrary, evangelical attention to angels has often been limited to the bare affirmation of their existence. This reticence reflects, to some extent, a proper emphasis on the centrality of God in Christ. Lengthy treatises on the characteristics of angels fall easy prey to the criticism that they divert us from the weightier matters of the Christian faith. Thus John Calvin wisely inserted a rule of theological modesty into his treatment of angels:

Let us remember here, as in all religious doctrine, that we ought to hold to one rule of modesty and sobriety: not to speak, or guess, or even to seek to know, concerning obscure matters anything except what has been imparted to us by

${ }^{1}$ A Revised form of the Tyndale Christian Doctrine Lecture, 1993. 
God's Word. Furthermore, we ought ceaselessly to endeavor to seek out and meditate upon those things which make for edification. ${ }^{2}$

This evangelical reticence about angels may also reflect our location in a culture which has been highly unsympathetic to the discussion of spiritual realities. Until relatively recently any assertion of belief in angels might well have been regarded as grounds for dismissing the speaker as 'pre-modern', 'precritical' or 'superstitious'. In such a context it made sense not to put too much stress on a peripheral doctrine which might hinder the presentation of the gospel.

However times are changing. Many commentators (by no means all of them Christian) predict the imminent demise of Modernity. One symptom of the current sea change in western culture is the dramatic resurgence of interest in spirituality. With the resurgence of spirituality has come a renewed popular interest in angels. Thus angels figure far more extensively in New Age thought than they have done in Christianity over the last two or three centuries.

At the same time angels have become a much more prominent feature of popular Christian thought. ${ }^{3}$ Unfortunately, the evangelical tradition of reticence about angels means that this interest often remains unsupported by sound biblical and theological teaching.

Any teaching which diverts our attention from the core of Christian faith to peripheral matters is dangerous. But, in the light of contemporary trends, our traditional reticence is no less dangerous. Commenting on demons, C.S. Lewis made the following oft-quoted remark: 'There are two equal and opposite errors into which our race can fall about the devils. One is to disbelieve in their existence. The other is to believe, and to feel an excessive and unhealthy interest in them.' ${ }^{4} \mathrm{~A}$

${ }^{2} \mathrm{~J}$. Calvin, Institutes of the Christian Religion (tr. F.L. Battles; Philadelphia: Westminster, 1960) 1:14:4.

${ }^{3}$ This has undoubtedly been fuelled to some extent by the tremendous popularity of Frank Peretti's supernatural thrillers amongst conservative Evangelicals. In some quarters these novels are even used as manuals for training in spiritual warfare.

${ }^{4}$ C.S. Lewis, The Screwtape Letters (London: G. Bles, 1942) 9. 
similar warning is applicable to the study of angels. Thus any responsible angelology must seek to steer between the Scylla of demythologising (or, perhaps, embarrassed silence) and the Charybdis of unhealthy speculation. We dare not address the subject in a fashion which diverts attention from the only One to whom worship is due. Conversely, we may no longer take refuge in silence.

\section{Barth's Contribution to Angelology}

No contemporary angelology can overlook the contribution of Karl Barth. His very extensive account of angels is virtually unique in contemporary Protestant theology. Most Protestant theologians have been content, following Schleiermacher, to consign angels to the outer darkness of popular Christian piety: a harmless belief perhaps but not one which need concern the scientific theologian. Not so Barth.

\section{The limits of angelology}

The most striking feature of Barth's angelology is the lengthy methodological section which forms the first part of his discussion. Here he underlines the importance of maintaining a via media 'between the far too interesting mythology of the ancients and the far too uninteresting "demythologisation" of most of the moderns', 5 which option he later dubs 'the angelology of the weary shrug of the shoulders' ${ }^{6}$ In fact this methodological discussion is nothing less than a critique of the entire Christian tradition of angelology.

(1) Angelology and natural theology. Barth accuses his predecessors of importing alien concepts into systematic theology through the medium of angelology. We may not recognise it as such because of the materialism of our science but, as Barth indicates, the doctrine of angels has been a major

${ }^{5} \mathrm{~K}$. Barth, Church Dogmatics, Vol. III: The Doctrine of Creation, Part 3 (tr. G.W. Bromiley and R.J. Ehrlich; Edinburgh, T. \& T. Clark, 1961) 369. 6Ibid., 413. 
pillar of natural theology. This is the proton pseudos against which he never tired of uttering his Nein!

Against the tradition, Barth asserts that there cannot be any legitimate natural basis for a Christian angelology. He certainly does not rule out the possibility of a science of spiritual beings. But he denies that this could ever be identified with a Christian theology of angels. There is no room for nonbiblical speculation here. In his own words, 'Angelology cannot be confused with a philosophy of angels, nor what the Bible says about angels interpreted in terms of such a philosophy."7

But is this a legitimate criticism of the tradition? The crucial figure in classical Christian angelology is undoubtedly the pseudonymous Dionysius. It is clear that Dionysius read the biblical references to angels very much in the light of neoPlatonic emanationism. 8 Of course his attempt to identify angels with entities recognised by the culture of his day was no theological innovation. On the contrary, it was a common feature of early Christian theology and may be traced back beyond the first Christian theologians to Philo who identified the angels with Plato's daimones or intermediary spirits. ${ }^{9}$

Moving on to St Thomas Aquinas, the doctor angelicus, we find a different cosmological background. Here the angels are clearly identified with the separate intelligences of Aristotelian metaphysics.10 Barth's comment on this identification is short and sharp:

On the basis of the Word of God attested in Holy Scripture we are not asked whether there are or are not substances of this kind, nor are we required to prove their existence in some

7Ibid., 412.

${ }^{8}$ Specifically, his theology is deeply indebted to the philosophy of Proclus and Iamblicus. See A. Louth, Denys the Areopagite (London: Chapman, 1989) 37.

${ }^{9}$ Louth, Denys the Areopagite, 35; Plato, Symposium, 202e-204a.

10For example, his Tractatus de substantiis separatis was written as a treatise in honour of the angels and simply assumes that Christian teaching about angels can be appended to an account of the Aristotelian position. 
way. If there are, and if their existence can be proved, this does not lead us to angels in the biblical sense of the term. ${ }^{11}$

To illustrate the ease with which alien concepts may be smuggled into Christian theology, consider the following 'common sense' argument for angels often used during the Middle Ages. There are various types of being: obviously God is uncreated spirit; at the other extreme there is created matter; between the two extremes there is humankind, an amphibian of created matter and created spirit. Clearly there is a missing category: that of created spirit. In fact, this is only clear if you take for granted the Hellenistic Principle of Plenitude, i.e., that every possible niche must be filled.

(2) Angelology and the priority of Scripture. However, Barth's methodological discussion is more than another blast against natural theology. Equally important is his assertion that, in angelology, we must always defer to the priority of Scripture. $\mathrm{He}$ insists that 'We are dealing wholly and exclusively with what are described and introduced as angels in the witness of Scripture and in connexion with the revelation and work of God.'12

But exclusive attention to Scripture does not imply that bare affirmations of the existence of angels are adequate. Another ever-present factor in Barth's thought is the credo ut intelligam. Simply to affirm what Scripture says and then to pass on in ignorance is not enough. For Barth, authentic Christian faith is a faith which is not content with ignorance.

There can be no question of a blind acknowledgement and acceptance of something perceptible in the Bible...We do not honour the authority of Scripture with due obedience, indeed, we are not dealing with its authority at all, if on its authority we try to hold a biblical doctrine of angels without taking the trouble to ask what it is that we really hold and how far we do so. 13

11Barth, op. cit., 393.

12Ibid., 372.

13Ibid., 373. 
Thus, if we are to attend exclusively to what Scripture has to say about angels this means wrestling with what Scripture says. It also means coming to terms with the literary forms of the biblical passages which introduce angels. For Barth, this means coming to terms with the presence of saga and legend in the Bible. Notice that this does not mean 'fiction'. Evangelicals have frequently misunderstood Barth at this point. However, for once, Barth is quite explicit that 'where historically verifiable history. . . passes over into historically non-verifiable saga or legend'14 we do not pass from truth to falsehood. On the contrary, 'There is real, spatio-temporal history which has this form', 15 i.e., of saga or legend.

However this does mean that angelology is not entirely reducible to propositions. There is more in legend than we can say-that is the raison d'être of legend. Thus, for Barth, angelology can 'be grasped only by divinatory imagination, and find expression only in the freer observation and speech of poetry'.16 To put it another way, when we are told to love God with all our minds this does not mean only our reasoning powers but also our imaginations. There is a place for a sanctified use of imagination in angelology. ${ }^{17}$ But such a use of the imagination must be disciplined and, interestingly, Barth chooses to cite Calvin's rule of theological modesty as a permanent limitation on angelology. 18

\section{The kingdom of heaven}

Barth does not move directly from the limits of angelology to an account of angels. Instead he interposes a section devoted to their context or environment, namely, heaven.

(1) Heaven as a creature. Barth stresses very strongly that heaven is not part of the divine being. There is no place coeternal with God within which God dwells.

${ }^{14}$ Ibid., 374.

15 Ibid.

16 Ibid.

${ }^{17}$ Consider, for example, C.S. Lewis' illuminating accounts of the eldila in his science-fiction trilogy.

${ }^{18} \mathrm{Op}$. cit., 370. 
Heaven, rather, is the counterpart of earth. If earth may be taken as representative of all that is visible in creation then heaven represents the invisible creation. In the words of the Creed, He is the creator of 'all things, visible and invisible'. If earth is all that is accessible, heaven is all that is inaccessible. If earth is all that is comprehensible, heaven is all that is incomprehensible. ${ }^{19}$

Positively, this invisible, inaccessible, incomprehensible dimension of creation is also the place, which by his grace, God has chosen as the created starting point of the divine movement towards the creature. By setting up his throne in heaven, God at once identifies himself with the creature and establishes the distance necessary for genuine personal relationship. ${ }^{20}$

(2) The mystery of creation. In fact, the incomprehensibility, inaccessibility and invisibility of heaven is not as negative as it might first appear. On the contrary, Barth presents heaven as 'the sum of all that which in creation is unfathomable, distant, alien and mysterious'. ${ }^{21}$ In other words, heaven rather than God (pace Jüngel) is the mystery of the world.

This implies that theologians must exercise the discipline of reserve. Heaven is a place, a part of creation, but we must respect its status as mystery. ${ }^{22}$ This need not rule out the kinds of insight to which Paul alludes when he says 'I know a man in Christ who fourteen years ago was caught up to the third heaven' (2 Cor. 12:2). But Paul adds 'He heard inexpressible things, things that man is not permitted to tell' (2 Cor. 12:4). That is what Barth is getting at. His call for reserve is a warning against a presumptuous gnosticism which, in the end, tells more than it can know. In his own words, 'Any attempt at an independent ontology of heaven would at once estrange us from this knowledge and lead us into the realm of an impossible, dangerous and forbidden desire for knowledge.'23 Such

${ }^{19}$ K. Barth, Dogmatics in Outline (tr. G.T. Thomson; London: SCM, 1949) 61.

${ }^{20}$ Barth, Church Dogmatics III, $432 \mathrm{f}$.

${ }^{21}$ Ibid., 424.

22Ibid., 442.

${ }^{23}$ Ibid. 
insights may be the stuff of spiritual experience, they may be the basis for prayer and poetry but they are not to be taken as the data for systematic theology.

(3) Angels as creatures. The existence of angels is a datum of Scripture. But to leave it at this might be to court the danger of Christian belief in angels being dismissed as arbitrary: one of the seven impossible things we are supposed to believe before breakfast. Barth's strictures against natural theology rule out common sense or philosophical arguments for their existence (at least in the context of Christian dogmatics). However, the habit of faith seeking understanding demands that there be a theological rationale for angels. Thus Barth goes on to discern the existence of angels as implicit in the structure of salvation history.

He asks us to consider the logic of the divine economy. God rules in heaven. This implies that there are heavenly events. But these are oriented by earthly events since God's heavenly rule is not autonomous of the earthly creation but, on the contrary, arises out of God's choice of heaven as the created starting point for his movement towards the creature. Since God's kingdom comes on earth through the events of history, it follows that there is a differentiation in the corresponding heavenly events. A differentiated heaven implies a heaven with its own denizens. 24

\section{The ambassadors of God}

Barth takes his cue for an account of angels from a New Testament passage which has traditionally been taken as definitive of angels: 'Are not all angels ministering spirits sent to serve those who will inherit salvation?' (Heb. 1:14).

However he accuses Christian theologians of focusing wrongly on the noun, 'spirits', and thus seeking to identify angels with what the world around them has understood as spirits. He argues that the correct focus should be on the adjective, 'ministering'.

${ }^{24}$ Ibid., 450. 
In other words, according to Barth, the biblical view of angels is an entirely functional one. The very context of this discussion reflects his functional emphasis: it is the concluding part of a chapter dominated by his treatment of God's providential care for the creature. Angels are discussed only as they appear in action as the servants of God in Christ relating us to the work of God in Christ. Indeed, they may not be treated independently of that work of God in Christ:

Strictly speaking, every angelological statement can only be an auxiliary or additional statement, an explanation and elucidation of. . the divine action in Jesus Christ and therefore of the divine lordship in the creaturely world..$^{25}$

It follows that angels are known only in relation to their service. ${ }^{26}$ There is no basis, within Scripture, for any definition or exposition of angels in terms of their being.

First and foremost, then, angels 'are in the service of God. It is their existence and nature to observe the will of God and stand at His disposal.'27 But, since the will of God is to call the creature into a personal relationship, it immediately follows that this service of God will be expressed in a service of the creature.

One aspect of this service of God and creature is particularly interesting. Earlier in his account Barth presented heaven as the mystery of creation. But, if angels are the inhabitants of heaven, they must be the bearers of that mystery. Thus Barth presents angels as the heralds of the mystery of God. Being the bearers and inhabitants of created mystery, it is appropriate that they proclaim the uncreated mystery. "There are more things in heaven and earth, Horatio, Than are dreamt of in your philosophy' (or theology for that matter). A world without angels would be a world without wonder. For Barth, a theology without angels is a theology without mystery. And, if our theology cannot accommodate the mystery of creation in the end it will fail to accommodate God. 


\section{Beyond Barth}

(1) The rejection of natural theology. In the specific context of angelology, Barth's critique of natural theology sounds a warning against two tendencies. First, there is the tendency to let alien concepts dominate. Whether those concepts are neoPlatonic ideas, Aristotelian separate intelligences or reflect the 19th and early 20th-century tendency to psychologise and demythologise, the effect is to raise the status of a particular cultural perspective to that of Christian dogma. Both classical and modern doctrines of angels display only too clearly the way in which Christian theology can become enmeshed in a particular culture through the agency of natural theology.

The second tendency is related to the first. If concepts other than scriptural ones have already been permitted to dominate our theology, it is quite natural to expect that concerns other than biblical ones may structure our theology. Take, for example, Dionysius. Barth comments without explanation that, in Dionysius, 'the biblical concern for its subject and therefore angels finds no place but is replaced by anoth$\mathrm{er}^{\prime}{ }^{28}$ Andrew Louth expands on this by pointing out that Dionysius was concerned to develop a hierarchical cosmology intended to legitimate the hierarchical structure of the Church. Angels were merely the building blocks in this cosmological scheme. ${ }^{29}$

Granted those dangers, I must nevertheless admit to a certain unease about Barth's rejection of natural theology-an unease which emerges from my missiological and apologetic concerns. There is also a danger of taking the rejection of natural theology too far.

The Christian Gospel does not simply stand over against human culture. Biblical language has not simply come out of the air. On the contrary, biblical language and concepts have specific cultural contexts. They have an etymological prehistory. For example, words such as God, deus, theos, elohim, Yahweh all bring with them a certain amount of pre-

28 Ibid., 388.

${ }^{29}$ Louth, Denys the Areopagite, 41. 
Christian cultural baggage. The translatability of the Bible depends upon a degree of continuity between Hebrew, Aramaic and Greek terminology and the terminology of the receptor culture. Furthermore, Bible translation presupposes that the pre-Christian cultural baggage of the receptor language in no way compromises the message of the Gospel. This has been a fundamental principle of cross-cultural mission ever since Paul identified the Christian God with the unknown god of the Athenians (Acts 17:23). If this were not so, Christianity would, like Islam, be forced to displace indigenous cultures with a specifically Christian culture.

What has this to do with natural theology and angelology? Simply this: that any call to eschew natural theology is a counsel of perfection. It is not realisable because every word we use in our theologies carries with it this cultural baggage. Even the words with which we communicate the content of the biblical message have this baggage. The naive assumption that by adhering to biblical concepts we can avoid the dangers of natural theology is a recipe for self-delusion and self-righteousness.

Barth, of course, did not make such a naive assumption (in spite of the impression created by some of his sharper comments about natural theology). Indeed, returning to angelology, does not Barth's own interpretation of heaven contain elements which cannot simply be read out of Scripture, specifically the notion of heaven as the mystery or depth of creation?

If we cannot seal our theology off from alien concepts then how are we to approach them? I believe that we must honestly recognise the extent to which we have adopted the preconceptions and terminology of our culture. That is not a problem. On the contrary the New Testament offers ample justification for such adoption. But then we must submit our formulations to the bar of scripture. This does not mean that we judge theology by simplistic biblical slogans but that we allow the rationale of scripture to judge and transform our language. This process may be discerned in the development of the doctrine of the Trinity: the simple biblical slogans proved inadequate (in fact, it was the heretics who took refuge in biblicism); but, in the development of adequate terminology the 
Fathers succeeded in transforming certain key concepts from Hellenistic philosophy. A similar process may be applicable to the doctrine of angels. Rather than stressing the limits we may be able to identify angels with concepts in contemporary culture. Having done so we must then engage in a dialogue between scripture and our understanding in which scripture gradually transforms our understanding. In this context, Barth's rejection of natural theology may be seen as an entirely healthy call for self-criticism: 'have I told more than can be said?'

(2) Barth and the activity of angels. One facet of Barth's angelology (as distinct from his methodology) particularly concerns me. He identifies their ministry with praise and witness. Thus 'Jesus Christ alone is the Lord of all things. Creatures, including the angels, can only praise Him and be His witnesses.' 30 Now, of course we should not restrict witness to verbal proclamation of the Gospel. But this should be made more explicit in this context. Angels are the witnesses of God precisely in their ministering activity. It is as the agents of divine providence that they bear witness to the Lordship of Christ.

There is too much emphasis on the divine-human axis within Barth's theology. Thus angels, in spite of his admission that they are the agents of providence and the bearers of the mystery of creation, are reduced to an entirely peripheral role. But there are more things in heaven and earth. Created reality is much more than the divine-human relationship. Barth is quite wrong to narrow the focus in this way.

And, even within this narrow focus, there is too much emphasis on the divine pole. Barth's insistence on divine sovereignty reduces human and angel alike to a state of overawed impotence. I would not for a moment wish to depart from the orthodox insistence that God is the exclusive source and agent of salvation. But why should this conflict with a genuine creaturely freedom in other respects?

${ }^{30}$ Barth, Church Dogmatics III, 462. 
In connection with angels, Barth's exclusive emphasis on praise and witness seriously underplays the power which biblical accounts appear to vest in such beings.

\section{Ministering Spirits}

\section{God's courtiers}

The Old Testament presents us with several pictures of the angels collectively forming a heavenly court (e.g., $1 \mathrm{Ki}$. 22:1922; Jb. 1:6ff). Since no king is complete without a court, these might be understood as primitive attempts to portray God's sovereignty. However they also point us towards the primary function of angels, namely, praise and worship (e.g., Dt. 32:43 [LXX]; Is. 6; Heb. 1:6; Rev. 5:11). Of course this is not the exclusive privilege of angels. When Barth says that 'Creatures, including the angels, can only praise $\mathrm{Him}$ and be $\mathrm{His}$ witnesses', he is reflecting a long tradition of regarding the enjoyment and glorification of God as the chief end of all creaturely existence.

Why is praise foundational? Because, as Dan Hardy and David Ford point out, 'praise perfects perfection' ${ }^{31}$ It is that condition of openness to God which enables God to pour forth still more blessings which are returned in ever-new forms of praise and so ad infinitum.

\section{God's deacons}

As God's courtiers, the angels are also God's servants; God's ministers. Earlier I noted that, for Barth, this was the essential feature of biblical angelology. Their role as the attendants of God is highlighted graphically by the evangelists. According to Matthew and Mark, angels attend Jesus after his wilderness encounter with Satan (Mt. 4:11; Mk. 1:13). Luke prefers to make the point in his reference to Jesus' prayer on the Mount of Olives (Lk. 22:43).

${ }^{31}$ D.W. Hardy and D.F. Ford, Jubilate: Theology in Praise (London: Darton, Longman \& Todd, 1986) 6. 


\section{Agents of revelation}

Both the Hebrew mal'ak and the Greek angelos primarily denote messengers. Angels are the messengers of God; the agents of divine revelation (e.g., Gn. 22:15-18; Judg. 13:3; $1 \mathrm{Ki}$. 19:5). This revelatory role of angels was greatly developed in Judaism extending even to the mediation of the Law (e.g., Dt. 33:2 [LXX]; Jub. 1:27). ${ }^{32}$ However, the New Testament is clear that this revelatory role has been supplanted by Christ. This is indicated by the striking distribution of references to angels in the Gospels. Angels are active at the birth of Christ (Lk. 1:11; 26, 2:9) and after his resurrection (Lk. 24:4); they attend to his needs after his temptation (Mt. 4:11; Mk. 1:13) and his ordeal in Gethsemane (Mt. 26:53; Lk. 22:43). But they play no part during his ministry. The point of this bracketing of Jesus' ministry is surely to indicate that one greater than the angels is here.

Subsequently angels are presented as the messengers of Christ (Acts 8:26; 10:3ff; 27:23; Rev. 1:1; 5:2; 10:1; 18:1; 19:17): they have no independent role. They certainly have no mandate to depart from the Gospel preached by Paul (Gal. 1:8).33

\section{Agents of providence}

Biblical accounts make it clear that the angels are also the agents of providence. Such accounts tend to focus on special providence; on the specific provision of aid to the faithful (e.g., 1 Ki. 19:5-7; Acts 5:19; 12:7-11). But Jewish and Christian traditions also envisage a role for angels in the execution of God's general providence.

The ancient notion of the angels of the nations (e.g., Dt. 32:8-9 [LXX]; Dn. 10:13; 10:20-11:1; 12:1) suggests that they were regarded as the guardians of social order: that behind every nation, tribe and social structure there is an angel moulding its character and maintaining its continuity through time. By extension, angels (whose primary function is, of

\footnotetext{
${ }^{32}$ This is reflected at various points in the New Testament, e.g., Acts 7:53; Gal. 3:19; Heb. 2:2.

33It is arguable that Paul's apparent references to a cult of angels are allusions to the different gospel being preached by the Judaisers. We may presume that the angelic mediation of the law would be one of their arguments in favour of its continuing importance.
} 
course, to worship God) might be regarded as the guarantors or guardians of order in public worship. ${ }^{34}$ This, in turn, may shed light on the puzzling New Testament concept of the angels of the churches. The modern tendency is to demythologise these into human representatives of a local congregation. However, there is clear evidence of a widespread belief in the existence of spiritual guardians overseeing local congregations amongst early Christians. ${ }^{35}$

Another ancient notion which has influenced traditional Christian angelology is that of the angels of nature. Prior to the emergence of mechanicism, Christians generally reckoned the world to be alive. Aquinas' identification of angels with the Aristotelian separate intelligences is perhaps the most sophisticated development of the angel of nature tradition since a major function of the separate intelligences was to maintain the natural motions of the cosmos.

Richard Hooykaas suggests that this tradition represents a compromise between Christianity and paganism, alleging that the separate intelligences or substantial forms are 'pagan "numina" in disguise' and 'the idols of a widespread superstition'. ${ }^{36}$ But this is an unfair criticism. The identification of the spiritual realities of paganism with angels (fallen or unfallen) need not be a paganisation of biblical Christianity. On the contrary, it may be a de-deification and relativisation of the pagan gods. For example, the stoicheia or elements were widely regarded as divine in the ancient world. However, by setting angels over them, 37 the Church Fathers effectively de-divinised the elements.

\section{The ubiquity of angelic ministry}

Part of Hooykaas' objection to the notion that angels might have a role in the ordering of nature stems from his insistence

34D. Guthrie, New Testament Theology (Leicester: IVP, 1981) 139f.

${ }^{35} \mathrm{~W}$. Wink, Unmasking the Powers: The Invisible Forces that Determine Human Existence (Philadelphia: Fortress, 1986) 69-71.

${ }^{36} \mathrm{R}$. Hooykaas, Religion and the Rise of Modern Science (Edinburgh: Scottish Academic Press, 1973) 25.

${ }^{37}$ E.g., 'there are angels in charge of everything, of earth, water, air and fire: all the elements alike' (Origen, Homily on Jeremiah, 10.6); cited by Wink, Unmasking the Powers, 207. 
on the omnicausality of God. Thus he asserts that 'The Bible. . attributes all events, however insignificant, immediately to God.' 38 But this is patently untrue. The Bible attributes all events ultimately to God but, as we have seen, it recognises that many of those events are mediated through creaturely causes and agents. Calvin is quite clear that God acts through angels. Thus he says, 'Because he exercises and administers his authority in the world through them, they are sometimes called principalities, sometimes powers, sometimes dominions.' 39

Take, for example, revelation. It is arguable that there is no unmediated revelation of God. God always meets us in and through the created order. That is the point of Barth's argument about heaven as the created starting point of God's movement towards the creature: heaven is the ultimate medium through which we encounter God but it remains part of the created order. To deny this, to assert the possibility of an immediate encounter with God, is to opt for mystical absorption into the Godhead rather than personal relationship. Personal relationship entails a degree of distance and otherness which is annihilated by immediacy.

Angels are not God but the revelations of angels are the revelations of God. They are God's self-effacing agents. 40 This serves to explain the way in which 'angel of the Lord' comes to be used as a periphrasis for God (e.g., Judg. 6:11-24; 13:2-23; Lk. 12:8; 15:10).

\section{Heavenly Creatures}

It is not enough to focus exclusively on the function of angels. The biblical definition of angels adopted by Barth was 'ministering spirits'. However much emphasis we put on the qualifying adjective 'ministering' we cannot escape from the fact that the noun 'spirits' remains part of the definition. Thus, contrary to what Barth suggests, the New Testament itself

38 Religion and the Rise of Modern Science, 13.

${ }^{39}$ Institutes, 1:14:5.

${ }^{40}$ Barth, Church Dogmatics III, 460. 
invites comparison between angels and what the world understands as spirits.

In reality even Barth, in spite of claims to the contrary, cannot avoid straying beyond an exclusive interest in the function of angels. This is so because he inserts a section on heaven into his angelology. Since angels are heavenly creatures, our understanding of angels will be strongly affected by our understanding of heaven. Barth may not make any explicit assertions about the nature of angels but a discussion of heaven cannot avoid making implicit assertions about their nature.

\section{Expressing otherness}

How are we to express the otherness of heaven and, hence, of angels? Clearly heaven is not earth. There is a legitimate duality in creation which must be acknowledged and articulated.

The early Church maintained the duality by speaking of creation as 'all things visible and invisible'. Thus earthly creation consists of what we can see, taste, touch, hear and smell. It is the realm of sense experience. But this by no means exhausts God's creation. There is another equally real dimension to it; that which is invisible. The human psyche provides a window onto a rich domain of intangibles which are nevertheless part of the created order. The philosopher of science Karl Popper often speaks of a third world: an objective but non-physical dimension of reality in which resides all actual and possible objective knowledge. ${ }^{41}$ In similar vein, John Polkinghorne speaks of a noetic realm which contains, amongst other things, all mathematical concepts. 42

An alternative and subsequently dominant way of expressing this otherness was to use spatial metaphors. Earth is 'below'; heaven is 'above'. This is suggested by some biblical

${ }^{41 E . g ., ~ K . R . ~ P o p p e r, ~ O b j e c t i v e ~ K n o w l e d g e: ~ A n ~ E v o l u t i o n a r y ~ A p p r o a c h ~}$ (Oxford: Clarendon, 1972) 106-28; 153-61.

42J. Polkinghorne, Science and Creation: the search for understanding (London: SPCK, 1988) 69-83. 
passages, e.g., accounts of the ascension. 43 The danger with this metaphor is that it also traditionally does duty for the transcendence and holiness of God. Thus there is a tendency for heaven to be displaced across the ontological divide between creature and creator; divorced from earth and assimilated to God. It becomes a higher plane; a holy place in its own right.

Recent theology has reasserted the created nature of heaven and, particularly through the work of Walter Wink, offered us yet another set of metaphors to express its otherness. This contemporary alternative could be summarised by saying that heaven is the inwardness of creation. Thus Wink presents 'heaven not as a super-terrestrial realm in the sky' but 'as the interiority of earthly existence in all its potentialities'. ${ }^{44}$ This is to make heaven immanent rather than transcendent. Thus it clearly distinguishes heaven from the transcendent being of God. At the same time it clearly maintains the Nicene duality of creation: creation consists of both the realm of sense phenomena and those mysterious 'depths of being which may alternately terrify and delight us'. .5

\section{In defence of inwardness}

This approach to heaven and its denizens has been subjected to severe criticism from certain evangelical quarters. Therefore I ought to say a few words in its defence.

The crux of this criticism is that such an approach is tantamount to a psychologisation of angels and demons. By speaking of principalities and powers as the inwardness, the spirituality, of everyday realities (physical phenomena, social structures, etc.) we are reducing them to the level of

\footnotetext{
${ }^{43}$ Though the connotation of motion to a higher plane is stronger in English translation than in the Greek of the New Testament. For

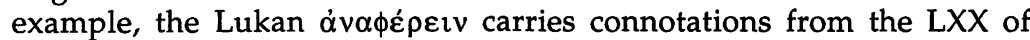
bearing gifts to the altar: the upward motion is a metaphor for entry into the holy place.

${ }^{44}$ Unmasking the Powers, 91.

45Barth, Dogmatics in Outline, 62.
} 
'projections', 'powerful psychological realities', 46 thus denying them objective reality.

The critics point particularly to Wink's admission that the work of Carl Jung has had a significant influence on his thinking. Ironically one of the major factors in Jung's feud with Freud was precisely the former's refusal to privatise the contents of the unconscious. Jung explicitly rejected the notion that the human unconscious consisted solely of repressed memories and other artefacts of our personal history. His study of dreams revealed recurring symbolic patterns which led him instead to postulate the existence of a collective unconscious.

Contrary to popular belief, Jung does not appear to have understood the collective unconscious as an ocean of spirit upon which individual personalities are merely so many ephemeral waves. Precisely what he understood by it is not entirely clear but it seems to have been something more like the fundamental genetic programming of the psyche rather than some mystical substratum connecting every human consciousness. In other words, our psyches share certain common features just as most human beings have one head, two arms, ten fingers, etc. It is collective in the sense that it is common to all of us rather than that there is only one of it.

Jung gave the name 'archetypes' to those common features of the collective unconscious. Many of his disciples regard them as explaining traditional accounts of spiritual experience and demonic possession. 47 The important point is that, contrary to his and Wink's critics, he does ascribe actual existence to the archetypes. They are not mere projections or personifications; they are the real inhabitants of this domain which he calls the collective unconscious.

46C.E. Arnold, Powers of Darkness (Leicester: IVP, 1992) 174. See also pp. 198f, where he asserts that the interpretation of angelic entities as the inwardness of created structures is a denial of their actual existence. 47Indeed, at a time when many Christian leaders were still flirting with Nazism, it was Jung who identified it as a case of possession: the possession of the German people by Wotan. See C.G. Jung, 'Wotan', in The Collected Works of Carl G. Jung, Vol. 10: Civilization in Transition (Princeton: Princeton UP, 1970). 
The criticism of inwardness as a metaphor for heaven may, in fact, amount to an assimilation of Christianity to the world-view of Modernity. Arnold takes for granted that the domain of the psyche (and, by extension, the inwardness of creation) is private and subjective, less real than the domain of physical phenomena. Thus to interpret angels as denizens of that inwardness is to relate them to psychological phenomena and thus to deny their reality. However, this denial of the reality of the subjective is an integral part of the dichotomy between public and private which is a hallmark of Modernity. Such criticisms suggest that, far from defending psychological and spiritual realities against the creeping privatisation of Modernity, much conservative Christianity has succumbed (albeit in a different way from that of liberal Christianity).48

\section{Angels and the depth of creation}

This location of angels in the inwardness or, better, depth 49 of creation is not a denial of their reality. On the contrary, it is a re-assertion of the reality of created intangibles over against the prevalent materialism of our age.

Creation is awesome; it is 'charged with the grandeur of God'; it possesses the capacity to evoke Otto's mysterium tremendum et fascinans. It is open to God. Moltmann suggests that we might identify heaven with this openness. 50 Thus heaven will also be the domain of God's creative possibilities for the world. A world which did not possess this duality of things visible and invisible, of tangible and intangible, would be closed, self-sufficient and meaningless: the world of secular materialism. A world without angels, without wonder, would indeed be a world without God.

${ }^{48}$ Further evidence of this could be adduced from the tendency of conservative Christians to ascribe a quasi-physical existence to spiritual creatures. See, for example, Frank Peretti's fantasy thrillers, in which angelic and demonic forces are presented as efficient causes in the physical domain.

49'Depth' is to be preferred to 'inwardness' since the latter suggests that the invisible creation is somehow bounded by the visible, whereas the former supposes no such limitations.

${ }^{50} \mathrm{~J}$. Moltmann, God in Creation: An ecological doctrine of creation (London: SCM, 1985) 163. 
What of angels? They are inhabitants of this invisible or spiritual dimension of created reality. To use the language suggested by Barth, they are bearers of this mystery. As we explore the mystery of creation we may experience some of its 'contours' as presences or entities which are best described in personal or quasi-personal terms. 51 If these encounters direct us beyond themselves to the triune God, we may rightly interpret them as messengers (angels) of God.

\section{The Relevance of Angels}

\section{The apologetic significance of angels}

Angelology has frequently been dismissed as futile speculation with no practical significance for the Christian life or mission. Such treatments of the subject may have been motivated by a desire to avoid putting unnecessary stumbling blocks in the way of predominantly secular materialist audiences. However, as the preceding discussion has suggested, the cost of such a move is high. For example, the abandonment of heaven as the mystery of creation and angels as its inhabitants has the effect of rendering the orthodox view of the relationship between God and creation problematic. 52

Understood as an apologetic tactic in the face of secular materialism, the abandonment of angelology was short-sighted. However, cultural changes render such abandonment dubious even as an apologetic tactic. The European Values Study has revealed a marked swing away from materialism during the 1980s.

At the forefront of this reaction against materialism is the New Age movement (or phenomenon). New Agers do not regard angels as the stuff of speculation. On the contrary, their fascination with angels is driven by a very practical desire for a

51Jungian psychology frequently presents the archetypes of the collective unconscious in such terms.

52If the world does not possess a depth dimension, an openness to God, deism is a more satisfactory way of understanding the God-world relation than the traditional theism. 
wholeness which integrates physical, psychological and spiritual realities.

That fascination and that desire are potentially important bridge points between Christians and New Agers. Using the metaphor of inwardness to express the concept of heaven and angels as its denizens offers an avenue of communication particularly with the (many) New Agers whose thinking has been influenced by Carl Jung.

\section{The glamour of the invisible}

Having acknowledged that angels are an important bridge point into the New Age, we should not succumb to the temptation to dwell too much on angels or their realm. The fascinating and terrifying mystery of creation is ambivalent. It may be a lens through which our eyes are guided to the glory of the Creator. On the other hand, we may be so fascinated by the glory of creation and the bearers of its mystery that we allow them to distract us from the greater glory of their creator. Thus we may be tempted to make them the object of our worship and so become fools (Rom. 1:22f.). As Barth rightly insists,

There can be no question of any special, autonomous or abstract experience of angels in and of themselves. The subjects of this kind of experience could not be the angels of God, but only ideas or ghosts or figments of the imagination or even demons and therefore the opponents of the genuine angels. 53

Authentic Christian experience of angels does not dwell upon the angels themselves. Angels are the messengers and agents of God. They perform their created function only insofar as the experience enables us to go beyond the angelic (the creature) to their creator. Undue concentration upon the angelic has the effect of distracting us from God. Thus, for example, the angelic messenger warns John not to worship him but rather direct his worship to the one who alone is worthy of that worship. That is the hallmark of a genuinely Christian encounter with an angel: it directs us to God.

53Barth, Church Dogmatics III, 477. 
For this reason, many Christian spiritual writers have warned against seeking visions of angels. For example, Evagrius of Pontus advises 'Do not desire to see sensibly, angels or powers or Christ, lest you become entirely delirious, accepting the wolf instead of the shepherd and worshipping the demon-enemy. ${ }^{\prime 54}$

\section{Entertaining angels}

However, this proper refusal to seek out the angelic is not at all the same as a refusal to entertain angels when they seek us out. The one is a legitimate avoidance of temptation, the other is an entirely illegitimate refusal to encounter the divine.

The divine vocation of the angels is to direct us beyond themselves to God. Thus, as the Orthodox point out, they call us to prayer. To quote Evagrius again, 'The holy angels urge us to prayer, and stand by us rejoicing, and pray for us. 55

Take, for example, the angels of nature. According to Cardinal Newman,

whenever we look abroad, we are reminded of those most gracious and holy Beings, the servants of the Holiest who deign to minister to the heirs of salvation. Every breath of air and ray of light and heat, every beautiful prospect, is, as it were, the skirts of their garments, the waving of the robes of those whose faces see God in heaven. ${ }^{56}$

They are the bearers of the mystery of creation. When we encounter the mystery of creation we are encountered by angels. Modernity has consistently denied the existence of such mystery. It has reduced mystery to the level of outstanding problems. In so doing it silenced the music of the spheres. According to Pascal, human beings facing a cosmos shorn of its mystery could only say, "The eternal silence of these infinite

${ }^{54}$ Cited by B. Krivoshein, 'Angels and Demons in the Eastern Orthodox Spiritual Tradition', in E.L. Mascall (ed.), The Angels of Light and the Powers of Darkness (London: Faith Press, 1954) 32.

55 On Prayer, 81.

56J.H. Newman, Parochial and Plain Sermons (London: Longmans, Green, 1896), Vol. 2, 362. 
spaces fills me with dread.'57 To entertain angels is to allow the horror vacui to become once again the mysterium tremendum which sings to us not of itself but of the glory of its creator.

Alternatively, consider the angels of the nations. Walter Wink has suggested that entertaining the existence of such spiritual guardians of social order may help us to understand more fully and respond more appropriately to the behaviour of human institutions and societies. He argues that social structures have a spiritual counterpart, a presence in the invisible angelic dimension of creation. However, since such entities must clearly participate in human fallenness, they are ambivalent.58 Thus Wink identifies them as the spiritual realities underpinning human oppression, violence and nationalism. Nevertheless our recognition of their reality has the potential to direct us to God in spite of them. Wink asks 'What advantages, what gains, lie in resuscitating this antiquated notion, so uncongenial to the modern temperament?' and answers his questions by arguing that 'it can help us to unmask a nation's apostasy more ruthlessly, discern its vocation more perceptively, and love it, despite its evils, more faithfully.'59 Recognising the actual existence of these spiritual counterparts of social structures has the potential to drive the social activist to prayer (because it reveals that action at the outer visible level is inadequate to bring about real change). Conversely, recognising that the principalities and powers are the inwardness of social phenomena may encourage the more spiritually-minded to engage them at the physical level as well as at the spiritual level. It underlines the fact that prayer and righteous action are correlatives.

To entertain angels is to entertain the possibility that anything around us may be a messenger of God. It is to be prepared to hear God's voice in the garden. It is to be willing to see God at work in the cloisters of Cambridge, in the leafy suburbs of Richmond, in the urban squalor of Easterhouse, in the shanty towns of Lima, in the battlefields of Bosnia.

57B. Pascal, Pensées (Harmondsworth: Penguin, 1966) 201.

${ }^{58}$ Compare the ambivalence of the biblical references to angels of the nations, particularly in Daniel.

${ }^{59}$ Wink, Unmasking the Powers, 99. 